\title{
Quality indicators for the assessment and management of pain in the emergency department: A systematic review
}

\author{
Antonia S Stang MDCM MBA MSc ${ }^{1,2,3}$, Lisa Hartling $\mathrm{PhD}^{4,5}$, Cassandra Fera $\mathrm{BHSc}^{6}$, \\ David Johnson $\mathrm{MD}^{1,3,7}$, Samina Ali MDCM ${ }^{4,8,9}$
}

\begin{abstract}
AS Stang, L Hartling, C Fera, D Johnson, S Ali. Quality indicators for the assessment and management of pain in the emergency department: A systematic review. Pain Res Manag 2014;19(6):e179. e190.

BACKGROUND: Evidence indicates that pain is undertreated in the emergency department (ED). The first step in improving the pain experience for ED patients is to accurately and systematically assess the actual care being provided. Identifying gaps in the assessment and treatment of pain and improving patient outcomes requires relevant, evidence-based performance measures.

OBJECTIVE: To systematically review the literature and identify quality indicators specific to the assessment and management of pain in the ED. METHODS: Four major bibliographical databases were searched from January 1980 to December 2010, and relevant journals and conference proceedings were manually searched. Original research that described the development or collection of data on one or more quality indicators relevant to the assessment or management of pain in the $\mathrm{ED}$ was included.

RESULTS: The search identified 18,078 citations. Twenty-three articles were included: 15 observational (cohort) studies; three before-after studies; three audits; one quality indicator development study; and one survey. Methodological quality was moderate, with weaknesses in the reporting of study design and methodology. Twenty unique indicators were identified, with the majority (16 of 20) measuring care processes. Overall, 91\% (21 of 23) of the studies reported indicators for the assessment or management of presenting pain, as opposed to procedural pain. Three of the studies included children; however, none of the indicators were developed specifically for a pediatric population.

CONCLUSION: Gaps in the existing literature include a lack of measures reflecting procedural pain, patient outcomes and the pediatric population. Future efforts should focus on developing indicators specific to these key areas.
\end{abstract}

Key Words: Emergency department; Pain assessment and management; Quality indicators; Systematic review

\section{Les indicateurs de qualité pour évaluer et prendre en charge la douleur à l'urgence : une analyse systématique}

HISTORIQUE : D'après les données probantes, la douleur n'est pas asse traitée en salle d'urgence (SU). La première étape pour atténuer l'expérience de la douleur chez les patients en SU consiste à évaluer les soins administrés de façon précise et systématique. Pour déterminer les lacunes dans l'évaluation et le traitement de la douleur et améliorer le résultat des patients, il faut des mesures de rendement pertinentes et fondées sur des faits probants.

OBJECTIF : Faire l'analyse systématique des publications et déterminer les indicateurs de qualité propres à l'évaluation et à la prise en charge de la douleur en SU.

MÉTHODOLOGIE : Les chercheurs ont interrogé quatre grandes bases de données bibliographiques entre janvier 1980 et décembre 2010 et fouillé manuellement les revues et délibérations de congrès ou colloques pertinents. Ils ont inclus les recherches originales qui décrivaient la mise sur pied ou la collecte de données sur au moins un indicateur de qualité propre à l'évaluation ou à la prise en charge de la douleur en SU.

RÉSULTATS : La recherche a permis d'extraire 18078 citations. Vingttrois articles ont été retenus : 15 études d'observation (cohortes), trois études avant-après, trois vérifications, une étude d'élaboration d'indicateurs de qualité et une enquête. La méthodologie était de qualité modérée, comportant des faiblesses dans la déclaration de la conception et de la méthodologie. Vingt indicateurs uniques ont été relevés, la majorité (16 sur 20) mesurant les processus de soins. Dans l'ensemble, $91 \%$ des études (21 sur 23) rendaient compte d'indicateurs pour l'évaluation ou la prise en charge de la douleur à la présentation, en opposition à la douleur causée par une intervention. Trois études incluaient les enfants. Cependant, aucun indicateur n'a été élaboré expressément pour la population pédiatrique.

CONCLUSION : Le peu de mesures reflétant la douleur liée à l'intervention, les résultats des patients et la population pédiatrique font partie des lacunes des publications actuelles. Les futurs efforts devraient porter sur l'élaboration d'indicateurs axés sur ces secteurs clés.

Policy makers, researchers and health care providers use quality indicators, or performance measures, to measure and improve the quality of care provided to patients. Previous research and experience has shown that quality indicators and performance measurement improve health care outcomes $(16,17)$. The first step in improving the treatment of pain for ED patients is to accurately and systematically assess the actual care being provided. Identifying gaps in the assessment and treatment of pain and improving patient outcomes requires relevant, evidence-based performance measures. Quality indicators have previously
Dain is the most common reason for seeking health care in the 1 Western world (1-3). Multiple national and international bodies, including the $\mathrm{WHO}$, have focused on the importance of pain management (4-6). Research has shown that inadequate pain treatment can have detrimental effects; it can result in extended length of hospitalization, slower healing, altered pain processing, depression, anxiety, and substantial social and economic costs to society $(5,7,8)$. Although pain is a common reason for visiting the emergency department (ED), evidence consistently indicates that pain is undertreated in the ED (9-15).
${ }^{1}$ Department of Pediatrics; ${ }^{2}$ Community Health Sciences, University of Calgary; ${ }^{3}$ Alberta Children's Hospital Research Institute, Calgary; ${ }^{4}$ Department of Pediatrics, University of Alberta; ${ }^{5}$ Alberta Research Centre for Health Evidence, Edmonton, Alberta; ${ }^{6}$ School of Physical and Occupational Therapy, McGill University, Montreal, Quebec; ${ }^{7}$ Departments of Physiology and Pharmacology, University of Calgary, Calgary; ${ }^{8}$ Department of Emergency Medicine, Faculty of Medicine and Dentistry, University of Alberta; ${ }^{9}$ Women and Children's Health Research Institute, Edmonton, Alberta

Correspondence: Dr Antonia S Stang, Departments of Pediatrics and Community Health Sciences, University of Calgary, Alberta Children's Hospital Research Institute, 2888 Shaganappi Trail, Calgary, Alberta T3B 6A8. Telephone 403-955-7493, fax 403-955-7552,

e-mail antonia.stang@albertahealthservices.ca 


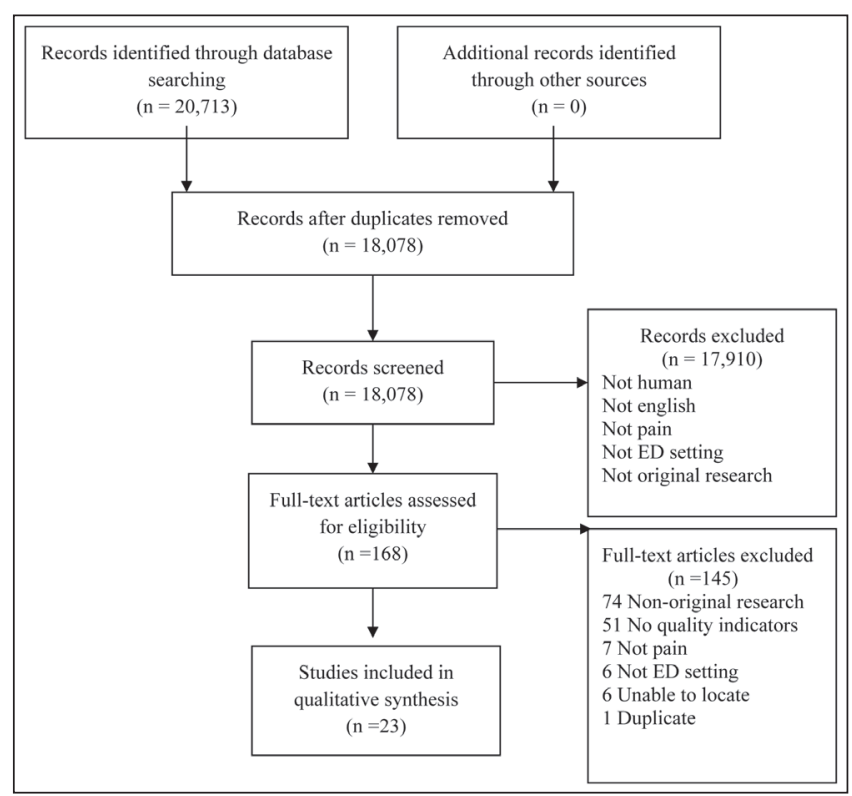

Figure 1) Preferred Reporting Items for Systematic Reviews and MetaAnalyses (PRISMA) diagram. ED Emergency department

been developed and applied to a number of clinical conditions and health care settings, including the ED management of asthma, acute myocardial infarction and pneumonia (18-22). The objective of the present study was to systematically review the literature and identify quality indicators for the assessment and management of pain in the ED setting. To create health care system improvements in the ED that meet the needs of patients with presenting (eg, illness or injury-related) and procedural (eg, medical test or other procedure-related) pain, an accurate summary of existing performance measures is required.

\section{METHODS}

\section{Literature search and selection}

The search strategy was developed by a medical research librarian (AM), in consultation with the research team and preidentified content experts. A commonly accepted definition of quality indicators that has been employed in previous research was used: "explicitly defined and measurable items referring to the structures (staff, equipment, and facilities), processes (prescribing, investigations, interactions between professionals and patients) or outcomes (such as mortality, morbidity or patient satisfaction) of care" (23-25). A systematic literature search of journals published between January 1980 and December 2010 was conducted using the following bibliographic databases: Medline, Cochrane Library, EMBASE and CINAHL. Search terms included those corresponding to quality indicators and quality improvement combined with terms describing the assessment and treatment of pain in the ED (Appendix 1). Due to resource constraints, only English-language publications were considered.

All titles and abstracts generated by the search were independently screened by two of three authors (AS, SA and CF) and any articles team members believed were likely to provide potential indicators were included for full-text review. Using predefined eligibility criteria, the full text of screened articles were independently assessed for inclusion by two authors (AS, CF). Original research that described the development or collection of data for one or more quality indicators relevant to the assessment or management of pain in the ED setting was included. Studies that were conducted outside of the ED, including the prehospital setting, inpatient setting or operating room were excluded, as were studies conducted in the ED that described the epidemiology, assessment or management of pain but did not measure the quality of care using quality indicators or a related term such as performance measure, audit filter, indicator, care indicator, benchmark, clinical path expected outcome or quality measure. To identify additional studies, reference lists of included articles and review papers were screened, and relevant journals and proceedings of key scientific meetings were hand searched (Appendix 2). Consensus was required for final exclusion of screened articles and disagreements were resolved through involvement of a third author (SA). Before implementation, ethics approval for this study was obtained from the University of Calgary's Conjoint Health Research Ethics Board (Calgary, Alberta).

\section{Data extraction}

Data were abstracted from each study by one of two authors (AS, CF) using a standardized, piloted form, with accuracy of extraction verified by the second author (AS, CF). Abstracted data included: study methodology (design, setting, population), indicator definition and indicator measurement properties (reliability, validity, data source) and the degree to which the quality indicator was judged to be operational (described explicitly and in sufficient detail to be potentially implemented by a reader) (26).

\section{Assessment of methodological quality}

Methodological quality was rated using the Newcastle-Ottawa Quality Assessment Scale (NOS) (27) for observational studies and a modified version of the NOS for before-after studies (28). To the authors' knowledge, there is no validated tool to measure the methodological quality of indicator development studies. The indicator development process used in included studies was compared with the steps recommended by the Agency for Healthcare Research and Quality for quality indicator measure development, implementation, maintenance and retirement (29) (Appendix 3).

\section{Analysis}

The results of the present review are primarily described in a qualitative manner, with the use of counts and proportions where relevant. The primary outcome was the count of existing quality indicators for the assessment and treatment of pain in the ED, including the type of indicator (structure [such as staff, equipment, and facilities], process [prescribing, investigations, interactions between professionals and patients] or outcome [such as mortality, morbidity or patient satisfaction]) (25) and the aspect of pain measured (assessment or management). Secondary outcomes included the indicator data source, the proportion of indicators that are operational, the results of indicator measurement, and the type of pain, either presenting (eg, musculoskeletal injury, abdominal pain, sickle cell crisis) or procedural (eg, fracture reduction, intravenous insertion, lumbar puncture).

\section{Study selection}

\section{RESULTS}

The search identified 18,078 citations (Figure 1). Review of titles and abstracts resulted in the retrieval of 168 full-text articles. No additional articles were identified through the manual search of references, journals or conference proceedings. Twenty-three articles met the inclusion and exclusion criteria for the present review (Appendix 4).

\section{Study characteristics}

The studies included in the review are described in Table 1; 15 of the studies were observational (cohort) studies, three were before-after studies, three were audits, one was a quality indicator development study and one was a survey. The number of patients enrolled in each of the studies ranged from 18 (30) to 156,729 (31), with a median of 302 patients. The majority of participants were adults. One study was performed in a pediatric ED (32), while three studies focused on pain in the elderly $(33-35)$. The majority $(n=10)$ of studies were performed in EDs in the United States, four in Australia, five in the United Kingdom, one in France and one in Canada; one study focused on indicator development, and was not health care facility-based.

Overall, there were weaknesses in the reporting of study design and methodology, which made assessment of methodological quality challenging for the present review. Methodological quality was 
TABLE 1

Summary of included studies

\begin{tabular}{|c|c|c|c|c|c|}
\hline Study & Study design & Setting (annual visits) & $\mathbf{n}$ & Age, years & Objective \\
\hline $\begin{array}{l}\text { Arendts and } \\
\text { Fry (69), } \\
2006\end{array}$ & $\begin{array}{l}\text { Retrospective } \\
\text { cohort }\end{array}$ & $\begin{array}{c}\text { ED, trauma centre, } \\
\text { Australia }(46,000)\end{array}$ & 857 & $\begin{array}{l}\text { Median } 47 \text { (range } \\
0-101)\end{array}$ & $\begin{array}{l}\text { To determine: the proportion of patients that require parenteral opiate } \\
\text { analgesia for pain in an ED and who receive the opiate in }<60 \mathrm{~min} \text {; } \\
\text { and whether any factors are predictive for the first dose of analgesia } \\
\text { being delayed beyond } 60 \mathrm{~min}\end{array}$ \\
\hline $\begin{array}{l}\text { Chu and } \\
\text { Brown } \\
\text { (44), } 2009\end{array}$ & $\begin{array}{l}\text { Analytic } \\
\text { observational }\end{array}$ & $\begin{array}{l}\text { ED, tertiary referral } \\
\text { hospital, Australia } \\
(70,000)\end{array}$ & 72 & $\begin{array}{l}\text { Median } 47 \text { (IQR } \\
35-56)\end{array}$ & $\begin{array}{l}\text { To provide exploratory data seeking an association between access } \\
\text { block and time to parenteral opioid analgesia in patients presenting } \\
\text { to the ED with renal colic }\end{array}$ \\
\hline $\begin{array}{l}\text { Eder et al } \\
\qquad(41), 2003\end{array}$ & Retrospective & $\begin{array}{l}\text { ED, United States } \\
\quad(\mathrm{NR})\end{array}$ & 261 & $\begin{array}{l}\text { Mean } \pm \text { SE } 40 \pm 15 \\
\text { median } 40\end{array}$ & $\begin{array}{l}\text { To evaluate ED documentation of patient pain in light of the Joint } \\
\text { Commission of Accreditation of Healthcare Organization's emphasis } \\
\text { on pain assessment and management }\end{array}$ \\
\hline $\begin{array}{l}\text { Forero et al } \\
(45), 2008\end{array}$ & $\begin{array}{l}\text { Retrospective } \\
\text { cohort }\end{array}$ & $\begin{array}{l}\text { ED, referral hospital, } \\
\text { Australia }(>40,000)\end{array}$ & 13,449 & $\begin{array}{l}23 \% 0-14,41 \% \\
15-44,26 \% \\
45-75,9 \% \geq 76\end{array}$ & $\begin{array}{l}\text { To explore the association of morphine use with factors influencing } \\
\text { time to initial analgesia }\end{array}$ \\
\hline $\begin{array}{l}\text { Goodacre } \\
\text { and }\end{array}$ & Audit & $\begin{array}{l}\text { ED, United Kingdom } \\
\text { (NR) }\end{array}$ & 200 & NR & $\begin{array}{l}\text { To evaluate a protocol for intervention used to improve on } \\
\text { shortcomings in the use of analgesia in an accident and ED }\end{array}$ \\
\hline
\end{tabular}

Roden

(39), 1996

Grant et al Retrospective

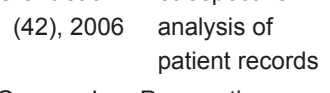

Guru and Prospective

Dubinski cohort

(49), 2000

Hawkes et Before-after

al (32),

2008

Hwang et al Retrospective

(43), 2008 observational

ED, United Kingdom

(NR)

ED, Canada (NR)

(

To evaluate the effectiveness of analgesia delivery, in the ED setting, to patients presenting with acute pain, with regard to guidelines from the British Association of Accident and Emergency Medicine

$71 \quad$ Mean \pm SE

$35.5 \pm 15.7$

To assess how well pain was evaluated and treated in accordance with recommended guidelines in the Canadian Association of Emergency Physicians consensus document

ED, third level trauma, Ireland $(50,000$, 10,000 pediatric)

ED, urban, academic tertiary care ED, United States (NR)

Hwang et al Retrospective (33), 2006 cohort

ED, tertiary care teaching facility, United States $(70,000)$

\begin{tabular}{|c|c|c|}
\hline $\begin{array}{l}\text { Jackson } \\
\qquad(34), 2010\end{array}$ & $\begin{array}{l}\text { Before-after } \\
\text { (educational } \\
\text { intervention) }\end{array}$ & $\begin{array}{l}\text { ED, United States } \\
(\mathrm{NR})\end{array}$ \\
\hline $\begin{array}{l}\text { Kuan et al } \\
(50), \\
2009)\end{array}$ & $\begin{array}{l}\text { Before-after } \\
\text { (educational } \\
\text { intervention) }\end{array}$ & $\begin{array}{l}\text { ED, tertiary referral } \\
\text { centre, Ireland } \\
(40,000)\end{array}$ \\
\hline
\end{tabular}

Mean 83 (range
$65-99)$

To describe the provision of analgesia for pediatric patients in a large

Before, median 8 (IQR 4-12); after, 10 (IQR 4-13) Irish ED and to analyse and modify the protocol in this hospital with

Mean \pm SD $47 \pm 19$ a view to improving the quality of care provided for children

Mean 83 (range 52-101) To evaluate the association of three
quality of general ED pain care

To evaluate the effect of ED crowding on the assessment and treatment of pain in older adults

Audit 1; median 38 (range 15-90) audit 2, 37 (16-83) audit 3 , 38 (15-82)

\begin{tabular}{|c|c|}
\hline $\begin{array}{l}\text { Mitchell et } \\
\text { al (46), } \\
2009\end{array}$ & $\begin{array}{l}\text { Observational } \\
\text { retrospective }\end{array}$ \\
\hline $\begin{array}{l}\text { Odesina et } \\
\text { al (30), } \\
2010\end{array}$ & $\begin{array}{l}\text { Retrospective } \\
\text { medical recor } \\
\text { review }\end{array}$ \\
\hline $\begin{array}{l}\text { Pines et al } \\
\qquad(54), 2008\end{array}$ & Retrospective \\
\hline $\begin{array}{l}\text { Pines and } \\
\text { Hollander } \\
\text { (48), } 2010\end{array}$ & $\begin{array}{l}\text { Retrospective } \\
\text { cohort }\end{array}$ \\
\hline
\end{tabular}

Pletcher et Analysis of al (31), national 2008
ED, metropolitan teaching hospital, Australia $(32,000)$

ED, suburban

university health care centre, United States $(29,200)$

ED, urban tertiary care, United States $(55,000)$

ED, United States, multicentre, academic tertiary care $(57,000)$, community hospital $(35,000)$

ED, United States, multicentre (NR)
Median 57

$18 \quad$ Mean \pm SE

$29.9 \pm 5.61$

13,758

5616

Mean \pm SD $39 \pm 16$

Mean \pm SD $44 \pm 17$ To study the association between ED crowding and the use of, and

156,729 Reported by race: To determine whether opioid prescribing in EDs has increased, white, mean \pm SE whether non-Hispanic white patients are more likely to receive an $39.0 \pm 22$; black, $34.3 \pm 19$; Hispanic, 31.9 \pm 20 ; Asian/ other, $36.7 \pm 21$ with a complaint of severe pain delays in, analgesia in patients with back pain in two EDs

To explore the results of a staff educational intervention with implementation

To evaluate the impact of a brief educational intervention on prompt recognition and treatment of pain in the ED

To determine whether overcrowding negatively impacts on the timeliness of pain management, an indicator of ED quality of care

To examine the current sickle cell disease pain management practice patterns, explore evidence-based sickle cell disease pain management clinical guidelines, and develop and implement an adapted ED sickle cell pain management clinical pathway

To study the impact of ED crowding on both treatment and delays in opioid than other racial/ethnic groups, and whether differential prescribing according to race/ethnicity has diminished since 2000 
TABLE 1 - CONTINUED

Summary of included studies

\begin{tabular}{|c|c|c|c|c|c|}
\hline Study & Study design & Setting (annual visits) & $\mathrm{n}$ & Age, years & Objective \\
\hline $\begin{array}{l}\text { Ritsema et } \\
\text { al (40), } \\
2007\end{array}$ & $\begin{array}{l}\text { Retrospective } \\
\text { cohort }\end{array}$ & $\begin{array}{l}\text { ED, multicentre, } \\
\text { United States (NR) }\end{array}$ & 2064 & $\begin{array}{l}\text { 1998-2000, mean } \pm \\
\text { SE } 33 \pm 1.2,2001- \\
2003,35 \pm 1.2\end{array}$ & $\begin{array}{l}\text { To compare the quality of ED pain management before and after } \\
\text { implementation of the Joint Commission on the Accreditation of } \\
\text { Healthcare organizations standards in } 2001\end{array}$ \\
\hline $\begin{array}{l}\text { Ricard- } \\
\text { Hibon et al } \\
\text { (36), } 2004\end{array}$ & Survey & $\begin{array}{l}\text { ED and prehospital } \\
\text { EMS, France, } \\
\text { multicentre }(23 \% \\
<15,000 ; 44 \%\end{array}$ & $\begin{array}{l}363 \\
\text { responses }\end{array}$ & NR & $\begin{array}{l}\text { To evaluate the existence of a quality control program for acute pain } \\
\text { management in the ED and in the prehospital EMS, and the needs } \\
\text { in training and support to implement these procedures. }\end{array}$ \\
\hline
\end{tabular}

Shah and Audit

Lendrum

(37), 2004

Tanabe et al Retrospective

(47), 2007 cohort
$<15,000 ; 44 \%$

$15,000-30,000 ; 33 \%$

$>30,000$ )

ED, United Kingdom $25 \quad$ NR

(NR)

ED, United States,

academic medical centres, multicentre (NR)

\begin{tabular}{|c|c|c|c|}
\hline $\begin{array}{l}\text { Terrell et al } \\
\text { (35), } 2009\end{array}$ & $\begin{array}{l}\text { Task force (quality } \\
\text { indicator } \\
\text { development) }\end{array}$ & & $\mathrm{N} / \mathrm{A}$ \\
\hline $\begin{array}{l}\text { Vega- } \\
\text { Stromberg } \\
\text { et al (38), }\end{array}$ & Audit & $\begin{array}{l}\text { Acute care, United } \\
\text { States, multicentre } \\
\text { (NR) }\end{array}$ & NR \\
\hline
\end{tabular}

To compare the practice in the Chesterfield Royal hospital ED with the standards set by The British Association of Accident and Emergency Medicine, and critically evaluate the results.

Mean \pm SE $32 \pm 10 \quad$ To characterize the initial management of patients with sickle cell disease and an acute pain episode, to compare these practices with the American Pain Society Guideline for the Management of Acute and Chronic Pain in Sickle-Cell Disease in the ED, and to identify factors associated with a delay in receiving an initial analgesic.

To develop ED-specific quality indicators for older patients

To describe an interdisciplinary model for process improvement within an integrated health care system.

2002

ED Emergency department; EMS Emergency medical services; IQR Interquartile range; NR Not recorded; SE Standard error; N/A Not applicable

TABLE 2

Summary of quality indicators and results of measurement

\begin{tabular}{|c|c|c|c|}
\hline Quality indicators & Type of indicator & $\begin{array}{l}\text { Studies reporting } \\
\text { indicator, } \mathbf{n}\end{array}$ & $\begin{array}{l}\text { Results of indicator measurement, } \\
\text { including range of results when similar } \\
\text { indicators were measured in multiple } \\
\text { studies }\end{array}$ \\
\hline \multicolumn{4}{|l|}{ Pain assessment } \\
\hline Patients with any documented pain assessment & Process & 5 & $57 \%$ to $94 \%$ \\
\hline Patients with documented pain assessment using validated pain score & Process & 1 & $23 \%$ \\
\hline Patients with physician-documented pain assessment & Process & 1 & $85 \%$ to $86 \%$ \\
\hline Timeliness of pain assessment & Process & 2 & Mean $40 \mathrm{~min}$ to $174 \mathrm{~min}$ (from arrival/triage) \\
\hline Patients with documented pain reassessment after treatment & Process & 4 & $32 \%$ to $50 \%$ \\
\hline Timely reassessment of pain relief after treatment & Process & 4 & $0 \%$ to $55.3 \%$ of patients, mean $113 \mathrm{~min}$ \\
\hline Pain assessment documented before discharge from ED & Process & 2 & $56 \%$ (of sites) \\
\hline Patients with pain rated $0 / 10$ at discharge & Process & 1 & $8 \%$ \\
\hline \multicolumn{4}{|l|}{ Pain management } \\
\hline Patients administered any analgesia & Process & 9 & $6 \%$ to $79 \%$ \\
\hline Patients with analgesia offered at triage & Process & 3 & $18 \%$ to $83 \%$ \\
\hline Timely access to any analgesia & Process & 12 & $\begin{array}{l}\text { Mean or median }>60 \text { min in } 6 \text { of } 9 \text { studies, } \\
\% \text { of patients with delay } \geq 1 \text { h } 14 \% \text { to } \\
81 \% \text { (from arrival/triage) }\end{array}$ \\
\hline Timely access to parenteral opioid analgesia & Process & 2 & $\begin{array}{l}\text { Median } 0.8 \mathrm{~h} \text { to mean } 67.5 \mathrm{~min} \text { from } \\
\text { arrival/triage }\end{array}$ \\
\hline Elderly patients treated with meperidine & Process & 2 & $32.8 \%$ \\
\hline Patients receiving appropriate analgesic dose & Process & 1 & $92 \%$ \\
\hline Patients receiving analgesic by appropriate route & Process & 1 & $55 \%$ \\
\hline Provision of bowel regimen with opioid analgesia prescription & Process & 1 & NR \\
\hline Sites with training specifically for pain management for physicians & Structure & 1 & $56 \%$ of sites \\
\hline Sites with training specifically for pain management for nurses & Structure & 1 & $68 \%$ of sites \\
\hline Sites with pain therapeutics protocols & Structure & 1 & $69 \%$ of sites \\
\hline Patients satisfied with pain management & Outcome & 1 & $34 \%$ to $39 \%$ \\
\hline
\end{tabular}

ED Emergency department; NR Not reported 
moderate (Appendix 3). The NOS was applied to studies described by the study authors or classified by data extractors as observational studies. Application of the NOS identified weaknesses in comparability of study groups and outcome ascertainment, particularly in the description of subjects lost to follow-up. For the studies identified by authors or data extractors as before-after studies, there were weaknesses identified in the selection of the pre- and postintervention sample as well as in outcome reporting and pre- and postintervention comparability with respect to the timeframe of data collection. The quality indicator development study demonstrated weaknesses in the assessment of candidate indicators. A quality assessment could not be completed for four studies due to study design, namely survey (36) and audit (37-39) methodology.

\section{Primary outcome}

Table 2 provides a summary of the quality indicators, the number of studies reporting each indicator and the results of data collected on the indicators. The most commonly measured indicators reflected the documentation and timeliness of pain assessment and reassessment, and the receipt and timeliness of analgesia. Table 3 provides details on the quality indicators extracted from each of the individual studies, including the type of indicator, data source, results of indicator measurement, extent to which indicator as reported is operational and type of pain. There were a total of 20 indicators measured, with considerable overlap in the indicators reported across studies. Eighty percent (16 of 20) of the indicators measured care processes, $15 \%$ (three of 20 ) measured structure and 5\% (one of 20) measured patient outcome. For the purposes of categorizing indicator type, indicators measuring pain assessment were considered process indicators. Sixty percent (12 of 20) of the indicators reflected pain management and 40\% (eight of 20) reflected pain assessment.

\section{Secondary outcomes}

Within the included studies, data for the specific indicators were abstracted from chart review (14 of 23), administrative databases (six of 23) and surveys (three of 23). Ninety-one percent of the studies (21 of 23) reported indicators reflecting presenting pain complaints. Some of the included studies evaluated the quality of pain assessment and management for patients with all types of presenting pain (10 of 23), while others focused on specific conditions including back pain, fractures, sickle cell disease, hip fracture and renal/biliary colic (11 of 23). The remaining studies did not specify presenting or procedural pain (two of 23). For 19 of 23 of the studies, our study team rated the indicators as operational (Table 3 ).

Data collected on the indicators in the individual studies are summarized in Tables 2 and 3. The proportion of patients with documentation of pain assessment ranged from $57 \%$ (40) to $94 \%$ (41) with $23 \%$ of assessments in the latter study measured using a validated pain scale. The proportion of patients with pain reassessment ranged from $32 \%(42)$ to $50 \%$ (43). For the studies that provided data on indicators reflecting time to analgesia (from arrival or triage), the mean or median was $>60 \mathrm{~min}$ in six of the nine studies $(30,32,33,43-48)$. The receipt and timing of analgesia varied according to pain severity and type of presenting pain. For example, in one study (49) the proportion of patients offered analgesia ranged from $6 \%$ for mild pain (score one to three of 10) to $68 \%$ for severe pain (score seven to 10 of 10 ). With respect to timing of analgesia, the proportion of patients in severe pain (score seven to 10 of 10) who received analgesia within $20 \mathrm{~min}$ of arrival or triage ranged from $24 \%$ (42) to $83 \%$ (50). In another study, $59 \%$ of patients with severe pain had a delay $>1 \mathrm{~h}$ in the time to first analgesic, when measured from triage presentation (48). With respect to specific types of presenting pain, the time to analgesia included a mean of $141 \mathrm{~min}$ (from triage) for hip fracture (33), a median of $48 \mathrm{~min}$ (from arrival) for renal colic (44) and a median of $90 \mathrm{~min}$ (from triage) for sickle cell pain crisis (47). One study measured patient satisfaction, with $34 \%$ to $39 \%$ of patients reporting 'excellent' satisfaction with pain management (38).

\section{DISCUSSION}

The increasing awareness of the prevalence and impact of untreated pain in the ED setting, and the growing body of evidence on this topic, precludes a comprehensive summary and review of all studies describing the epidemiology, assessment and management of pain in the ED. As such, we chose to focus on studies that provided quality indicators for the assessment and management of pain in the ED. Our approach enabled us to provide data on performance using existing indicators and to identify important gaps in measurement and quality improvement that are relevant to clinicians, administrators and researchers. Our comprehensive review has identified a total of 20 indicators. While previous work has focused on reviewing existing quality indicators for trauma care $(26,51)$, pediatric emergency medicine (52) and palliative care (53), to the best of our knowledge, this is the first publication to systematically review quality indicators specific to the assessment and management of pain in the ED.

\section{Clinical implications}

The clinical implications of the present review are directly relevant to nurses, physicians and administrators alike. Although a significant proportion of patients in the studies reviewed had documentation of pain assessment, few patients were assessed using a validated pain scale. An even smaller proportion of patients had documentation of pain reassessment. Given the negative implications of delays in pain treatment, these findings highlight the importance of encouraging the use of a validated pain scale, and conducting and documenting pain reassessments. It is imperative that pain not only be measured with a valid, objective tool, but also be frequently reassessed to optimize pain management. Our results further suggest that there are delays in the receipt of analgesia, even for patients in severe pain (48) or with clinical conditions known to be associated with significant pain (47). A number of the included studies identified an association between ED crowding and delays in pain management $(33,43,45,48,54)$. An awareness of the impact of crowding on pain management may help to further focus the attention of individual caregivers and hospital administrators on the importance of adequate and timely pain management.

\section{Research implications}

A key finding of the present review is that $91 \%$ of the identified indicators were specific to presenting pain only. The importance of procedural pain management and the harmful effects of such pain, when left untreated, have long been recognized (8,55-59). Poor management of procedural pain has been documented in multiple care settings including hospitalized children (60), children and adults in acute and critical care settings $(61)$, and adults in the ED $(13,62)$. The relative lack of indicators for procedural pain highlights a significant gap in measurement and a potential missed opportunity for quality improvement.

Previous research has documented variation in pain management based on patient demographic characteristics including race, age and sex (63-68). Results from one of the studies included in the present review indicate that although opioid prescribing in the United States for patients with a pain-related ED visit increased after national quality improvement efforts in the 1990s, differences according to race and ethnicity have not diminished (31). With respect to sex, one of the included studies demonstrated a longer time to analgesia for female patients with acute pain compared with men (47). Other identified factors associated with delays in analgesia that deserve further exploration included language barriers (46) and insurance status (Medicaid) (40). Delays in analgesia were also more likely among children (69) and elderly patients $(40,69)$, suggesting that those at the extremes of the age spectrum are suboptimally assessed and treated for acute pain. Although many of the reviewed studies included or focused on elderly patients, few of the studies included children and none of the indicators were specific to the pediatric population. Given the particular vulnerability of neonates, infants and children to both the short- and long-term consequences of untreated pain $(8,55-57)$, the lack of pediatric-specific pain indicators for the ED represents another important gap in the existing quality measurement and improvement literature.

A final gap identified in the present review was the lack of measures reflecting patient-focused outcomes. Previous work involving 
TABLE 3

Detailed summary of results of data collection on quality indicators

\begin{tabular}{|c|c|c|c|c|c|c|c|}
\hline \multirow{2}{*}{$\begin{array}{l}\text { Study } \\
\text { Arendts and Fry } \\
\text { (69), } 2006\end{array}$} & \multirow{2}{*}{$\begin{array}{l}\text { Quality indicator } \\
\text { Delay to analgesia (\% of patients with time } \\
\text { from arrival to analgesia } \geq 60 \mathrm{~min} \text { ) }\end{array}$} & \multirow{2}{*}{$\begin{array}{l}\text { Type* }^{*} \\
\text { Process }\end{array}$} & \multirow{2}{*}{$\begin{array}{l}\text { Data source } \\
\text { Administrative } \\
\text { database }\end{array}$} & \multirow{2}{*}{$\frac{n^{\dagger}}{857}$} & \multirow{2}{*}{$\begin{array}{l}\text { Result } \\
47 \%\end{array}$} & \multicolumn{2}{|c|}{ Operational ${ }^{\ddagger}$ Type of pain $\S$} \\
\hline & & & & & & Yes & Presenting, all types \\
\hline \multirow[t]{2}{*}{$\begin{array}{l}\text { Chu and Brown } \\
\text { (44), } 2009\end{array}$} & $\begin{array}{l}\text { Time to parenteral opioid analgesia (time of } \\
\text { arrival to parenteral opioid) }\end{array}$ & Process & Chart review & 69 & $\begin{array}{l}\text { Median } 0.80 \mathrm{~h}(\mathrm{IQR} \\
0.37 \mathrm{~h} \text { to } 1.37 \mathrm{~h})\end{array}$ & Yes & $\begin{array}{l}\text { Presenting, renal } \\
\text { colic }\end{array}$ \\
\hline & Time to parenteral opioid analgesia $(\% \leq 1 \mathrm{~h})$ & Process & Chart review & 69 & $60.9 \%$ & Yes & $\begin{array}{l}\text { Presenting, renal } \\
\text { colic }\end{array}$ \\
\hline \multirow{4}{*}{$\begin{array}{l}\text { Eder et al (41), } \\
2003\end{array}$} & $\%$ patients with initial pain assessments & Process & Chart review & 261 & $94 \%$ & Yes & Presenting, all types \\
\hline & $\begin{array}{l}\% \text { of patients with initial pain assessments } \\
\text { measured using pain scale }\end{array}$ & Process & Chart review & 261 & $23 \%$ & Yes & Presenting, all types \\
\hline & $\begin{array}{l}\% \text { of patients with documented pain } \\
\text { assessment subsequent to therapy }\end{array}$ & Process & Chart review & 261 & $39 \%$ & Yes & Presenting, all types \\
\hline & $\begin{array}{l}\% \text { of patients with documented pain } \\
\text { assessment subsequent to therapy } \\
\text { measured using pain scale }\end{array}$ & Process & Chart review & 261 & $19 \%$ & Yes & Presenting, all types \\
\hline $\begin{array}{l}\text { Forero et al (45), } \\
2008\end{array}$ & $\begin{array}{l}\text { Time to analgesia (time from triage to } \\
\text { administration of morphine) }\end{array}$ & Process & Chart review & 1097 & $\begin{array}{l}\text { Median } 79 \text { min, } \\
95 \% \mathrm{Cl} 71-85\end{array}$ & Yes & Presenting, all types \\
\hline \multirow{2}{*}{$\begin{array}{l}\text { Goodacre and } \\
\text { Roden (39), } \\
1996\end{array}$} & $\begin{array}{l}\text { Percent of fracture clinic referrals with no } \\
\text { analgesia offered in ED }\end{array}$ & Process & Chart review & 200 & $\begin{array}{l}\text { Initial audit } 91 \% \\
\text { repeat audit } 69 \%\end{array}$ & No & $\begin{array}{l}\text { Presenting, MSK, } \\
\text { fracture }\end{array}$ \\
\hline & $\begin{array}{l}\% \text { of orthopedic admissions with no analge- } \\
\text { sia offered in ED }\end{array}$ & Process & Chart review & 200 & $\begin{array}{l}\text { Initial audit } 39 \% \\
\text { repeat audit } 22 \%\end{array}$ & No & $\begin{array}{l}\text { Presenting, MSK, } \\
\text { fracture }\end{array}$ \\
\hline \multirow[t]{3}{*}{$\begin{array}{l}\text { Grant et al (42), } \\
2006\end{array}$} & $\begin{array}{c}\% \text { of patients in severe pain (score } 7 \text { to } 10 / 10 \text { ) } \\
\text { who receive appropriate analgesia within } 20 \\
\text { min of arrival or triage (whichever is earlier) }\end{array}$ & Process & $\begin{array}{l}\text { Administrative } \\
\text { database }\end{array}$ & 213 & $24 \%$ & Yes & Presenting, all types \\
\hline & $\begin{array}{l}\% \text { of patients in moderate pain (score } 4 \text { to } \\
6 / 10 \text { ) offered analgesia at triage }\end{array}$ & Process & $\begin{array}{l}\text { Administrative } \\
\text { database }\end{array}$ & 105 & $18 \%$ & Yes & Presenting, all types \\
\hline & $\begin{array}{l}\% \text { of patients who have documented } \\
\text { re-evaluation of analgesia requirements }\end{array}$ & Process & $\begin{array}{l}\text { Administrative } \\
\text { database }\end{array}$ & NR & $32 \%$ & Yes & Presenting, all types \\
\hline \multirow[t]{4}{*}{$\begin{array}{l}\text { Guru and Dubinsky } \\
\text { (49), } 2000\end{array}$} & $\begin{array}{l}\% \text { patients offered analgesia for mild pain } \\
\text { (score } 0 \text { to } 3 / 10 \text { ) }\end{array}$ & Process & Survey & 71 & $6 \%$ & Yes & Presenting, all types \\
\hline & $\begin{array}{l}\% \text { analgesia offered for moderate pain (score } \\
4 \text { to } 6 / 10 \text { ) }\end{array}$ & Process & Survey & 71 & $18 \%$ & Yes & Presenting, all types \\
\hline & $\begin{array}{l}\% \text { analgesia offered for severe pain (score } 7 \\
\text { to } 10 / 10 \text { ) }\end{array}$ & Process & Survey & 71 & $68 \%$ & Yes & Presenting, all types \\
\hline & $\%$ rating no pain (score $0 / 10$ ) on discharge & Process & Survey & 71 & $8 \%$ & Yes & Presenting, all types \\
\hline \multirow[t]{3}{*}{$\begin{array}{l}\text { Hawkes et al (32), } \\
2008\end{array}$} & $\begin{array}{l}\text { Time from triage to analgesia major fracture } \\
\text { (long bone, rib, clavicle) }\end{array}$ & Process & Chart review & 36 & $\begin{array}{l}\text { Pre median } 54 \text { min } \\
\text { (IQR } 25 \text { to } 90 \text { ); Post } \\
\text { median } 7 \text { min (IQR } \\
4 \text { to } 12 \text { ); P=0.0004 }\end{array}$ & Yes & $\begin{array}{l}\text { Presenting, major } \\
\text { fracture }\end{array}$ \\
\hline & $\begin{array}{l}\% \text { receiving analgesia major fracture (long } \\
\text { bone, rib, clavicle) }\end{array}$ & Process & Chart review & 36 & $\begin{array}{l}\text { Pre } 55.6 \% \text {; post } \\
61.1 \% \mathrm{P}=0.735\end{array}$ & Yes & $\begin{array}{l}\text { Presenting, major } \\
\text { fracture }\end{array}$ \\
\hline & Time from triage to analgesia other diagno- & Process & Chart review & 183 & Pre median 14 min & Yes & Presenting, all types \\
\hline
\end{tabular}

$$
\text { ses }
$$

$\%$ receiving analgesia other diagnoses

Hwang et al (33), \% of patients with documentation of pain 2006

Time to pain assessment by a physician

(from triage)

$\%$ of patients with documentation of administration of pain medication

Time to pain treatment (from triage)

$\%$ of patients receiving opioid who were treated with meperidine

Hwang et al (43), \% of patients with physician documented 2008

Process

Chart review

183

Process

Chart review

Process

Chart review

Chart review

Process

Process

Chart review

Process

Chart review

Process

Chart review

Process

73

$\%$ of patients with any documented pain assessment

(IQR 4 to 45); Post median 6 min (IQR 6 to 61$) \mathrm{P}=0.794$

Pre $34.7 \%$; post $39.8 \%$

$72.8 \%$

Mean 40 min (range $0 \mathrm{~min}$ to $600 \mathrm{~min}$ )

$64.1 \%$

Mean $141 \mathrm{~min}$ range (10 $\mathrm{min}$ to $525 \mathrm{~min}$ ) $32.8 \%$

1068 Census low: $86 \%$, Census high: $85 \%$

Chart review 1068 Census low: $90 \%$ Census high: $90 \%$
Presenting, all types

Presenting, hip fracture

Presenting, hip fracture

Presenting, hip fracture

Presenting, hip fracture

Presenting, hip fracture

Presenting, all types

Yes Presenting, all types 
TABLE 3 - CONTINUED

Detailed summary of results of data collection on quality indicators

\begin{tabular}{|c|c|c|c|c|c|c|c|}
\hline Study & Quality indicator & Type* $^{*}$ & Data source & $n^{\dagger}$ & Result & Operational ${ }^{\ddagger}$ & Type of pain§ \\
\hline \multirow[t]{5}{*}{$\begin{array}{l}\text { Hwang et al (43), } \\
2008\end{array}$} & $\%$ of patients with follow-up pain assessment & Process & Chart review & 961 & $\begin{array}{l}\text { Census low: } 50 \% \\
\text { Census high: } 47 \%\end{array}$ & Yes & Presenting, all types \\
\hline & $\begin{array}{l}\% \text { of patients who received analgesic } \\
\text { medication }\end{array}$ & Process & Chart review & 642 & $\begin{array}{l}\text { Census low: } 65 \% \\
\text { Census high: } 55 \%\end{array}$ & Yes & Presenting, all types \\
\hline & Time to first clinician pain assessment & Process & Chart review & 899 & $\begin{array}{l}\text { Census low: mean } \\
106 \text { min, } \\
\text { Census high: } \\
\text { mean } 174 \text { min }\end{array}$ & Yes & Presenting, all types \\
\hline & Time to first analgesic medication ordering & Process & Chart review & 604 & $\begin{array}{l}\text { Census low: mean } \\
104 \text { min, } \\
\text { Census high: } \\
\text { mean } 136 \text { min }\end{array}$ & Yes & Presenting, all types \\
\hline & $\begin{array}{l}\text { Time to first analgesic medication } \\
\text { administration }\end{array}$ & Process & Chart review & 590 & $\begin{array}{l}\text { Census low: mean } \\
125 \text { min, } \\
\text { Census high: } \\
\text { mean167 min }\end{array}$ & Yes & Presenting, all types \\
\hline \multirow[t]{2}{*}{$\begin{array}{l}\text { Jackson (34), } \\
2010\end{array}$} & $\begin{array}{l}\text { Time to first pain treatment after assessment } \\
(\%<60 \mathrm{~min})\end{array}$ & Process & Chart review & 220 & $\begin{array}{l}\text { Pre } 41.8 \% \text {; post } \\
50 \%\end{array}$ & Yes & $\begin{array}{l}\text { Presenting, hip } \\
\text { fracture }\end{array}$ \\
\hline & $\begin{array}{l}\text { Time to reassessment documentation after } \\
\text { treatment }(\%<60 \mathrm{~min})\end{array}$ & Process & Chart review & 149 & $\begin{array}{l}\text { Pre } 30.9 \% \text {; post } \\
55.3 \%\end{array}$ & Yes & $\begin{array}{l}\text { Presenting, hip } \\
\text { fracture }\end{array}$ \\
\hline \multirow{4}{*}{$\begin{array}{l}\text { Kuan et al (50), } \\
\text { 2009) }\end{array}$} & $\%$ of patients with analgesia offered at triage & Process & Chart review & 151 & $43 \%$ & Yes & Presenting, all types \\
\hline & $\begin{array}{l}\% \text { of patients with analgesia offered at triage } \\
\text { for severe pain ( } \leq 20 \text { min of arrival or at } \\
\text { triage for severe pain [score } 7 \text { to } 10 / 10])\end{array}$ & Process & Chart review & 24 & $83 \%$ & Yes & Presenting, all types \\
\hline & $\begin{array}{l}\% \text { of patients with timely reassessment of } \\
\text { pain relief (within } \leq 30 \text { min for } 90 \% \text { of } \\
\text { patients with severe pain [score } 7 \text { to } 10 / 10 \text { ]) }\end{array}$ & Process & Chart review & 19 & $0 \%$ & Yes & Presenting, all types \\
\hline & $\begin{array}{l}\% \text { of patients with timely treatment of pain } \\
\text { ( } \leq 60 \text { min of arrival for }>75 \% \text { of patients with } \\
\text { moderate pain [score } 4 \text { to } 6 / 10 \text { ]) }\end{array}$ & Process & Chart review & 64 & $14 \%$ & Yes & Presenting, all types \\
\hline $\begin{array}{l}\text { Mitchell et al (46), } \\
2009\end{array}$ & Time to analgesia (from ED arrival) & Process & Chart review & 232 & $\begin{array}{l}\text { Median } 53 \text { mins } \\
\text { (IQR } 30.5 \text { to } 114.5)\end{array}$ & Yes & $\begin{array}{l}\text { Presenting, fracture, } \\
\text { renal/biliary colic }\end{array}$ \\
\hline \multirow[t]{2}{*}{$\begin{array}{l}\text { Odesina et al } \\
(30), 2010\end{array}$} & Time from registration to receiving first opioid & Process & Chart review & 44 & $\begin{array}{l}\text { Mean } \pm \text { SD } \\
67.5 \pm 48.1 \mathrm{~min}\end{array}$ & Yes & $\begin{array}{l}\text { Presenting, sickle } \\
\text { cell disease }\end{array}$ \\
\hline & $\begin{array}{l}\text { Time to reassessment for pain relief after first } \\
\text { opioid administration }\end{array}$ & Process & Chart review & 44 & $\begin{array}{l}\text { Mean } \pm \text { SD } \\
113 \pm 118.4 \mathrm{~min}\end{array}$ & Yes & Presenting, all types \\
\hline \multirow{3}{*}{$\begin{array}{l}\text { Pines and } \\
\text { Hollander (54), } \\
2008\end{array}$} & $\begin{array}{l}\% \text { of patients with severe pain (score } 9 \text { to } \\
10 / 10 \text { ) with no analgesia in the ED }\end{array}$ & Process & $\begin{array}{l}\text { Administrative } \\
\text { database }\end{array}$ & 13,758 & $51 \%$ & Yes & Presenting, all types \\
\hline & $\begin{array}{l}\% \text { of patients with severe pain (score } 9 \text { to } 10 / 10 \text { ) } \\
\text { with delay }>1 \mathrm{~h} \text { in time to analgesia from triage }\end{array}$ & Process & $\begin{array}{l}\text { Administrative } \\
\text { database }\end{array}$ & 6746 & $59 \%$ & Yes & Presenting, all types \\
\hline & $\begin{array}{l}\% \text { of patients with severe pain (score } 9 \text { to } \\
10 / 10 \text { ) with delay }>1 \mathrm{~h} \text { in time to analgesia } \\
\text { from placement in room }\end{array}$ & Process & $\begin{array}{l}\text { Administrative } \\
\text { database }\end{array}$ & 1319 & $20 \%$ & Yes & Presenting, all types \\
\hline \multirow[t]{5}{*}{$\begin{array}{l}\text { Pines et al (48), } \\
2010\end{array}$} & $\begin{array}{l}\% \text { of patients with administration of any anal- } \\
\text { gesia }\end{array}$ & Process & $\begin{array}{l}\text { Administrative } \\
\text { database }\end{array}$ & 5616 & $79 \%$ & Yes & $\begin{array}{l}\text { Presenting, back } \\
\text { pain }\end{array}$ \\
\hline & Time from triage to first analgesia & Process & $\begin{array}{l}\text { Administrative } \\
\text { database }\end{array}$ & 4425 & $\begin{array}{l}\text { Median } 130 \text { min } \\
\text { (IQR } 73 \text { to } 217)\end{array}$ & Yes & $\begin{array}{l}\text { Presenting, back } \\
\text { pain }\end{array}$ \\
\hline & $\begin{array}{l}\% \text { of patients with delay of } \geq 1 \mathrm{~h} \text { from triage to } \\
\text { analgesia }\end{array}$ & Process & $\begin{array}{l}\text { Administrative } \\
\text { database }\end{array}$ & 4425 & $81 \%$ & Yes & $\begin{array}{l}\text { Presenting, back } \\
\text { pain }\end{array}$ \\
\hline & Time from room placement to analgesia & Process & $\begin{array}{l}\text { Administrative } \\
\text { database }\end{array}$ & 4425 & $\begin{array}{l}\text { Median } 86 \text { min (IQR } \\
51 \text { to } 135)\end{array}$ & Yes & $\begin{array}{l}\text { Presenting, back } \\
\text { pain }\end{array}$ \\
\hline & $\begin{array}{l}\% \text { of patients with delay of } \geq 1 \mathrm{~h} \text { from room } \\
\text { placement to analgesia }\end{array}$ & Process & $\begin{array}{l}\text { Administrative } \\
\text { database }\end{array}$ & 4425 & $67 \%$ & Yes & $\begin{array}{l}\text { Presenting, back } \\
\text { pain }\end{array}$ \\
\hline $\begin{array}{l}\text { Pletcher et al } \\
\text { (31), } 2008\end{array}$ & $\begin{array}{l}\% \text { of patients receiving opioid analgesic } \\
\text { prescription for pain-related visits }\end{array}$ & Process & $\begin{array}{l}\text { Administrative } \\
\text { database }\end{array}$ & 156,729 & $\begin{array}{l}29 \%(95 \% \text { Cl } 28 \% \\
\text { to } 30 \%)\end{array}$ & Yes & Presenting, all types \\
\hline \multirow[t]{3}{*}{$\begin{array}{l}\text { Ricard-Hibon et al } \\
\text { (36), } 2004\end{array}$} & $\begin{array}{l}\% \text { of sites with training specifically for pain } \\
\text { management for physicians }\end{array}$ & Process & Survey & 356 & $56 \%$ & No & Presenting, all types \\
\hline & $\begin{array}{l}\% \text { of sites with training specifically for pain } \\
\text { management for nurses }\end{array}$ & Process & Survey & 356 & $68 \%$ & No & Presenting, all types \\
\hline & $\%$ of sites with pain therapeutics protocols & Process & Survey & 356 & $69 \%$ & Cor & $\begin{array}{l}\text { Presenting, all types } \\
\text { ntinued on next page }\end{array}$ \\
\hline
\end{tabular}


TABLE 3 - CONTINUED

Detailed summary of results of data collection on quality indicators

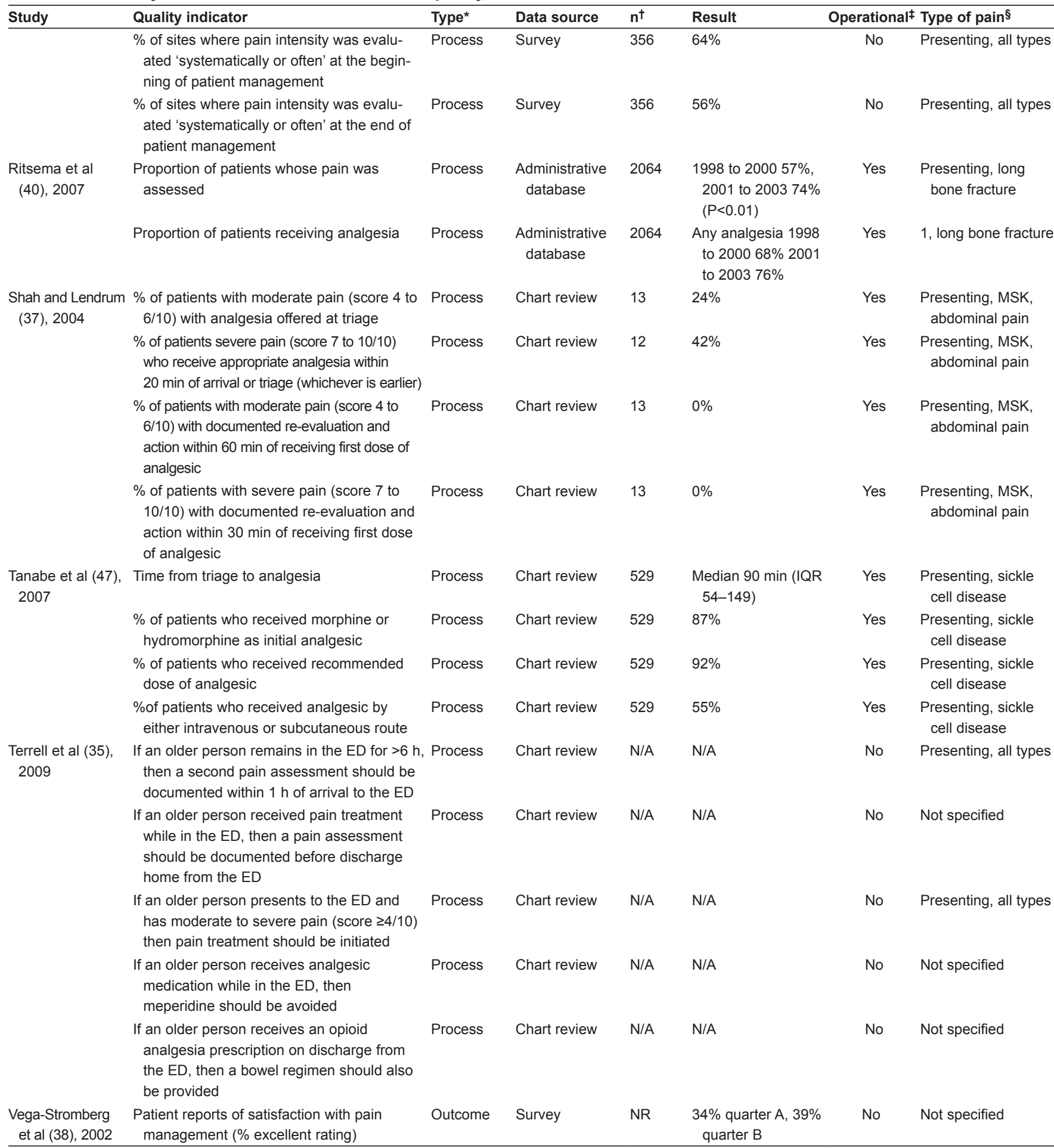

${ }^{*}$ Type of indicator: Process, Structure, Outcome; ${ }^{\dagger}$ Number of subjects; $¥$ Operational: described explicitly and in sufficient detail to be potentially implemented by a reader; §Type of pain: presenting or procedural pain, condition/illness. IQR Interquartile range, MSK Muskuloskeletal; N/A Not applicable, NR Not recorded

performance measurement has highlighted the importance of outcome indicators or, at a minimum, evidence of a link between the process of care and patient outcome $(70,71)$. There was only one outcome indicator identified in the present review (patient satisfaction) (38). Research on the link between pain management and patient satisfaction has generated conflicting results (72-74) and the utility of isolated measurement of patient satisfaction with pain management as a quality improvement tool has been questioned (14). Other potentially relevant and complementary outcomes that warrant further exploration include achievement of pain reduction to the level desired by the patient, quality of life measures, absence from work/school due to pain and pain-related health care visits/admissions. Were these measures to be considered alongside patient satisfaction, we may then have a more comprehensive understanding of patient-level outcomes.

Although many studies have suggested that oligoanalgesia in the ED is both a common and long-standing problem $(10-14,75,76)$, a 
recent commentary has questioned whether this is true, citing the retrospective nature of the majority of these studies (77). Retrospective data cannot account for patient preference, pain perception and appropriate medical justifications for avoiding analgesia. Furthermore, chart abstraction has variable reliability, and documentation (or lack thereof) does not necessarily reflect analgesia administration (77). Most of the studies included in the present review are subject to the same criticisms. Despite this recent controversy, it is clear that awareness and documentation of pain and its management are, at best, suboptimal. Given that modification of clinical behaviour begins with recognition of the problem, improvements in documentation of patient care and objective measures of quality of care will likely result in better patient outcomes. In addition to further prospective research on pain management, the development of patient-centred outcome indicators and work linking process measures to these patient outcomes would help to clarify the degree to which our current analgesia practices impact the patient.

\section{Strengths and limitations}

The strengths of the present review include its comprehensive search strategy, clearly defined eligibility criteria and standardized data extraction. The main weakness of the present review was the variability in study design of included articles, and weaknesses in their description of methodology, outcome assessment and reporting. This made it difficult to compare performance on the indicators among studies. Furthermore, there is no validated quality assessment tool for before-after studies or quality indicator development studies. We mitigated this limitation by using a version of the NOS adapted for before-after studies and rated the quality indicator development study against the indicator development and assessment process, as outlined by the Agency for Healthcare Research and Quality. Additionally, much of the data on the quality indicators is based on chart review and administrative databases. The reliability and accuracy of these data sources for measures of true analgesia provision has, as previously discussed, been raised (77). Finally, our search did not include any literature after December 2010; however, given the large number of screened articles identified, resource limitations prevent further updating of the search.

\section{CONCLUSION}

The present review provides a summary of existing quality indicators for pain assessment and management in the ED setting. From a clinical perspective, the results highlight the importance of pain assessment and reassessment using a validated pain score and the potential for delays in analgesia administration, particularly at times when the ED is busy. We also identified gaps in existing performance measures, including a lack of measures for procedural pain and those specific to the pediatric population. Finally, the present review highlights the need for further work linking process measures to patient outcomes. These results can serve as the foundation for future work aimed at generating a complete list of quality indicators that will comprehensively measure the assessment and management of pain in the ED setting and establish a link between measurement of the indicators and patient outcomes.

DISCLOSURES: All authors listed have contributed substantially to the manuscript. This project was supported by an Alberta Innovates Health Solutions (AIHS) Knowledge Transfer/Innovation Research Grant secured by Drs A Stang and S Ali. Dr L Hartling holds a New Investigator Salary Award from the Canadian Institutes of Health Research (CIHR). The funding source (AIHS) had no involvement in data collection, analysis or interpretation. None of the authors were paid to write this article. The corresponding author (Dr A Stang) had full access to all the data and had final responsibility for the decision to submit for publication. All authors have no financial relationships with any organizations that might have an interest in the submitted work. All authors have no other relationships or activities that could appear to have influenced the submitted work. This work has not been submitted or accepted for previous publication.

ACKNOWLEDGEMENTS: The authors thank Andrea Milne, who conducted the literature search.

DISCLOSURES: All authors have no financial relationships with any organizations that may have an interest in the submitted work. All authors have no other relationships or activities that could appear to have influenced the submitted work.

\section{APPENDIX 1: MEDLINE* SEARCH STRATEGY}

$\mathrm{MeSH}$ and key words for quality indicators:

1. $\exp$ Quality Indicators, Health Care/

2. exp "Quality of Health Care"/

3. exp Quality Assurance, Health Care/

4. $\exp$ Clinical Competence/

5. exp Guideline Adherence/

6. exp "Outcome and Process Assessment (Health Care)"/

7. exp Peer Review, Health Care/

8. exp Program Evaluation/

9. $\exp$ Practice Guideline/

10. exp Practice Guideline as Topic/

11. exp Patient Care Management/

12. exp Benchmarking/

13. exp "Outcome Assessment (Health Care)"/

14. exp "Process Assessment (Health Care)"|

15. (adherence adj3 guideline*).tw

16. quality performance measure.tw

17. (performance adj3 guideline*).tw

18. (program adj 3 evaluat*).tw

19. (performance adj3 evaluat*).tw

20. (quality adj3 assess*).tw

21. (quality adj3 improv*).tw

22. OR/1-23

$\mathrm{MeSH}$ and keywords for emergency care:

23. exp Emergency Medicine/

24. exp Emergency Medical Services/

25. exp Emergency Service, Hospital/

26. exp Emergencies/

27. exp Ambulatory Care/

28. exp Critical Care/

29. exp Trauma Centers/

30. exp Emergency Nursing/

31. exp Emergency Treatment/

32. emergency department*.tw

33. (emergency adj3 admission*).tw

34. (emergency adj3 admit*)

35. emergency room*.tw

36. emergency ward*.tw

37. acute care.tw

38. (ED or ER).tw

39. (EDs or ERs).tw

40. (emergenc\$ adj5 (department $\$$ or ward $\$$ or unit $\$$ or room $\$$ or hospital $\$$ or care or patient $\$$ or physician $\$$ or doctor $\$$ or treatment\$)).tw

41. emergency unit*.tw

42. emergency care.tw

43. (trauma adj (centres or centers)).tw

44. (emergency or emergencies).jn

45. OR/23-44

46.22 (quality indicator terms) AND 45 (emergency terms) 
$\mathrm{MeSH}$ and key words terms for pain:

47. exp Pain/

48. exp Neuralgia/

49. $\exp$ Nociceptors/

50. pain.tw

51. exp Pain Measurement/

52. exp Pain threshold/

53. (pain adj2 management).tw

54. (pain adj 2 assessment).tw

55. (pain adj (scale or score)).tw

56. exp Analgesia/

57. exp Anesthesia/

58. exp "Anesthesia and Analgesia"|

59. analgesi $\$ /$ tw

60. an?esthes\$.tw

61. OR/50-60

62. 46 (quality indicator and emergency terms) AND 61 (pain terms)

63. Limit year to "1980-Current"

*The search strategy was translated as appropriate for the other databases

\section{APPENDIX 2}

Journals and conference proceedings

\begin{tabular}{|c|c|}
\hline Journals & Conference proceedings \\
\hline Academic Emergency Medicine & American Academy of Pediatrics \\
\hline Annals of Emergency Medicine & American College of Emergency \\
\hline BMJ Quality and Safety & Physicians \\
\hline Canadian Journal of Emergency Medicine & Canadian Association of \\
\hline Canadian Medical Association Journal & Emergency Physicians \\
\hline The Journal of Emergency Medicine & Pediatric Academic Societies \\
\hline Journal of the American Medical & Society for Academic \\
\hline Association & Emergency Medicine \\
\hline \multicolumn{2}{|l|}{ New England Journal of Medicine } \\
\hline Pediatrics & \\
\hline
\end{tabular}

\section{APPENDIX 3: SUMMARY OF METHODOLOGICAL QUALITY ASSESSMENT: TABLE 1}

Observational studies (Newcastle Ottawa Scale) ${ }^{\dagger}$

\begin{tabular}{|c|c|c|c|}
\hline Article & Selection ${ }^{\ddagger}$ & Comparability§ & Outcomeף \\
\hline Arendts and Fry (69), 2006 & $* * * *$ & $* *$ & ** \\
\hline Chu and Brown (44), 2009 & $* * * *$ & * & * \\
\hline Eder et al (41), 2003 & $* * *$ & * & * \\
\hline Forero et al (45), 2008 & $* * * *$ & ** & ** \\
\hline Grant et al (42), 2006 & *** & & ** \\
\hline Guru and Dubinsky (49), 2000 & $\star * \star *$ & & * \\
\hline Hwang et al (43), 2008 & $* * * *$ & ** & ** \\
\hline Hwang et al (33), 2006 & $* * * *$ & ** & * \\
\hline Mitchell et al (46), 2009 & $* * * *$ & $* *$ & * \\
\hline Odesina et al (30), 2010 & $* * *$ & & * \\
\hline Pines and Hollander (54), 2008 & $* * * *$ & ** & ** \\
\hline Pines et al (48), 2010 & $* \star * *$ & ** & ** \\
\hline Pletcher et al (31), 2008 & $* * * *$ & * & ** \\
\hline Ritsema et al (40), 2007 & $* * * *$ & * & ** \\
\hline Tanabe et al (47), 2007 & $* * * *$ & ** & * \\
\hline Maximum & $* * * *$ & ** & $* * *$ \\
\hline
\end{tabular}

${ }^{+}$Not completed for four studies due to study design (one survey [Ricard-Hibon 2004 (56)] and three audits [Goodacre 1996 (25), Shah 2004 (62), VegaStromberg 2002 (76)]). ¥Maximum of four stars for: representativeness of the exposed cohort; selection of the nonexposed cohort; ascertainment of exposure; and demonstration that outcome of interest was not present at start of study; $\S$ Maximum of two stars for: comparability of cohorts on the basis of the design or analysis; "Maximum of three stars for: assessment of outcome; was follow-up long enough for outcome to occur; and adequacy of follow-up of cohorts
APPENDIX 3: TABLE 2

\section{Before-after studies (adapted from Newcastle Ottawa} Scale)

\begin{tabular}{|c|c|c|c|c|c|}
\hline & & & & & $\begin{array}{l}\text { Pre- and } \\
\text { post inter- } \\
\text { vention }\end{array}$ \\
\hline Article & Selection $^{\dagger}$ & Comparability ${ }^{\ddagger}$ & $\ddagger$ Outcome ${ }^{\S}$ & $\S$ Intervention & ๓ periods ${ }^{\dagger \dagger}$ \\
\hline $\begin{array}{l}\text { Hawkes et } \\
\text { al (32), } \\
2008\end{array}$ & & * & $* *$ & & \\
\hline $\begin{array}{c}\text { Jackson } \\
(34) \\
2010\end{array}$ & & & & ** & \\
\hline $\begin{array}{l}\text { Kuan et al } \\
(50), \\
2009)\end{array}$ & & * & $* * *$ & ** & \\
\hline Maximum & $* * *$ & * & $\star * * * * *$ & ** & ** \\
\hline
\end{tabular}

${ }^{t}$ Maximum of three stars for: representativeness of the postintervention group; representativeness of the preintervention group; pre-post intervention groups drawn from the same source. $¥$ Maximum of one star for: comparability of the pre- and postintervention groups on the basis of design or analysis. \$Maximum of five stars for: validity of outcome assessment; reliability/accuracy of outcome assessment; method of outcome assessment the same for pre-and postintervention groups. TMaximum of two stars for: reporting point in time that intervention occurs; clearly describing intervention. ${ }^{+t}$ Maximum of two stars for: pre and postintervention data collected during similar time frame

APPENDIX 3: TABLE 3

Quality assessment of included indicator development study ${ }^{\dagger}$

\begin{tabular}{lcc}
\hline Article & $\begin{array}{l}\text { Identification of } \\
\text { candidate indicators }\end{array}$ & $\begin{array}{l}\text { Assessment of } \\
\text { candidate indicators } \S\end{array}$ \\
\hline Terrell et al (35), 2009 & ${ }^{* *}$ & ${ }^{*}$ \\
Maximum & ${ }^{* * *}$ & $* * * * * * *$
\end{tabular}

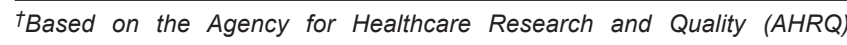
Document on Quality Indicator Measure Development, Implementation, Maintenance, and Retirement; $¥$ Maximum of three stars for: literature review to identify candidate indicators; development of conceptual model; expert engagement. \$Maximum of seven stars for: initial specifications; literature review on evidence base for candidate indicators; panel review using modified Delphi or Nominal Group process; risk adjustment; empirical analysis; finalization of specifications; summary of evidence for each recommended indicator

\section{APPENDIX 4: INCLUSION CRITERIA FOR FULL TEXT REVIEW}

Objective: To identify existing quality indicators for the assessment and management of pain in the ED and acute care setting.

Definitions

Quality of care is defined by the Institute of Medicine (IOM) as the "degree to which health services for individual's increases the likelihood of desired health outcomes and are consistent with current professional knowledge".

Quality indicators are explicitly defined and measurable items referring to the structures (staff, equipment, and facilities), processes (prescribing, investigations, interactions between professionals and patients) or outcomes (such as mortality, morbidity or patient satisfaction) of care.

Alternate terms for quality indicators: performance measure, audit filter, indicator, care indicator, benchmark, clinical path expected outcome, quality measure.

Screening Questions.

1. Is the article in English?

Yes: go to question 2 
No: Exclude and mark as 1-Not English

2. Is the complete article available?

Yes: go to question 3

No: Exclude and mark as 2-Abstract only (we will find full references for these)

3. Are the subjects of the article human?

Yes: go to question 4

No: Exclude and mark as 3-Not Human

4. Is this article a Duplicate?

Yes: Exclude and mark as 4-Duplicate and link to duplicate article by highlighting both in same color

No: go to question 5

5. Is the article original research?

Yes: go to question 6

No: Exclude and mark as 5-Not original research

Examples of original research include:

Systematic Reviews and Meta-analysis

Experimental studies (randomized controlled trials, cluster randomized controlled trials, nonrandomized trials)

Observational studies (cohort study, case-control study, case report, case-series, ecological study, survey, audit, time-series analysis)

Consensus methodologies (systematic methods to combine expert

\section{REFERENCES}

1. Cordell WH, Keene KK, Giles BK, Jones JB, Jones JH,

Brizendine EJ. The high prevalence of pain in emergency medical care. Am J Emerg Med 2002;20:165-9.

2. Johnston CC, Gagnon AJ, Pepler CJ, Bourgault P. Pain in the emergency department with one-week follow-up of pain resolution. Pain Res Manag 2005;10:67-70.

3. Tanabe P, Buschmann M. A prospective study of ED pain management practices and the patient's perspective.

J Emerg Nurs 1999;25:171-7.

4. The assessment and management of acute pain in infants, children, and adolescents. Pediatrics 2001;108:793-7.

5. Brennan F, Carr DB, Cousins M. Pain management: A fundamental human right. Anesth Analg 2007;105:205-21.

6. Gordon DB, Dahl JL, Miaskowski C, et al. American pain society recommendations for improving the quality of acute and cancer pain management: American Pain Society Quality of Care Task Force. Arch Intern Med 2005;165:1574-80.

7. Anand KJ. Pain, plasticity, and premature birth: A prescription for permanent suffering? Nat Med 2000;6:971-3.

8. Weisman SJ, Bernstein B, Schechter NL. Consequences of inadequate analgesia during painful procedures in children. Arch Pediatr Adolesc Med 1998;152:147-9.

9. Brown JC, Klein EJ, Lewis CW, Johnston BD, Cummings P. Emergency department analgesia for fracture pain. Ann Emerg Med 2003;42:197-205.

10. Ducharme J. Acute pain and pain control: State of the art. Ann Emerg Med 2000;35:592-603.

11. Ngai B, Ducharme J. Documented use of analgesics in the emergency department and upon release of patients with extremity fractures. Acad Emerg Med 1997;4:1176-8.

12. Petrack EM, Christopher NC, Kriwinsky J. Pain management in the emergency department: patterns of analgesic utilization. Pediatrics 1997;99:711-4.

13. Singer AJ, Richman PB, Kowalska A, Thode HC Jr. Comparison of patient and practitioner assessments of pain from commonly performed emergency department procedures. Ann Emerg Med 1999;33:652-8.

14. Todd KH, Ducharme J, Choiniere M, et al. Pain in the emergency department: Results of the pain and emergency medicine initiative (PEMI) multicenter study. J Pain 2007;8:460-6.

15. Johnston CC, Gagnon AJ, Fullerton L, Common C, Ladores M, Forlini S. One-week survey of pain intensity on admission to and discharge from the emergency department: A pilot study. J Emerg Med 1997;16:6.

16. Lee TH. Eulogy for a quality measure. N Engl J Med 2007;357:1175-7.

17. Bradley EH, Holmboe ES, Mattera JA, Roumanis SA, Radford MJ, Krumholz HM. A qualitative study of increasing beta-blocker use after myocardial infarction: Why do some hospitals succeed? JAMA 2001;285:2604-11. opinion and medical evidence including consensus development conference, Guideline Based, Nominal Group Technique, Delphi (or modified Delphi) Technique, Rand/UCLA appropriateness method)

Examples of non-original research include: letters to the editor, commentaries, nonsystematic reviews, book chapters, guideline, news items

6. Does the article include the development or collection of data on one or more quality indicators?

Yes: Go to question 7

No: Exclude and mark as 6-No Quality Indicators

7. Does the article contain quality indicators relevant to the assessment or treatment of pain?

Yes: Go to question 8

No: Exclude and mark as 7-Not Pain

8. Does the article contain quality indicators relevant to the assessment or management of pain in the ED setting?

Yes: Go to question 9

No: Exclude and mark as 8-Not ED setting

9. Is there another reason for exclusion?

Yes: Exclude and mark as 9 with explanation for reason No: Include

18. Graff L, Stevens C, Spaite D, Foody J. Measuring and improving quality in emergency medicine. Acad Emerg Med 2002;9:1091-107.

19. Lindsay P, Schull M, Bronskill S, Anderson G. The development of indicators to measure the quality of clinical care in emergency departments following a modified-delphi approach. Acad Emerg Med 2002;9:1131-9.

20. Mourad SM, Hermens RP, Nelen WL, Braat DD, Grol RP, Kremer JA. Guideline-based development of quality indicators for subfertility care. Hum Reprod 2007;22:2665-72.

21. McGory ML, Shekelle PG, Ko CY. Development of quality indicators for patients undergoing colorectal cancer surgery. J Natl Cancer Inst 2006;98:1623-33.

22. Guru V, Anderson GM, Fremes SE, O'Connor GT, Grover FL, Tu JV. The identification and development of Canadian coronary artery bypass graft surgery quality indicators. J Thorac Cardiovasc Surg 2005;130:1257.

23. Campbell SM, Braspenning J, Hutchinson A, Marshall MN. Research methods used in developing and applying quality indicators in primary care. BMJ 2003;326:816-9.

24. Campbell SM, Cantrill JA, Roberts D. Prescribing indicators for UK general practice: Delphi consultation study. BMJ 2000;321:425-8.

25. Donabedian A. The quality of care. How can it be assessed? JAMA 1988;260:1743-8.

26. Stelfox HT, Bobranska-Artiuch B, Nathens A, Straus SE. A systematic review of quality indicators for evaluating pediatric trauma care. Crit Care Med 2010;38:1187-96.

27. Wells GA, Shea B, O'Connell D, et al. The Newcastle-Ottawa Scale (NOS) for assessing the quality of nonrandomised studies in meta-analyses. Ottawa: Ottawa Health Research Institute. <www. ohri.ca/programs/clinical_epidemiology/oxford.asp > (Accessed December 11, 2013).

28. Bond KO, Blitz S, Friesen C, et al. Interventions to reduce overcrowding in emergency departments. Technology Report 67.4. Ottawa: Canadian Agency for Drugs and Technologies in Health, 2006.

29. Quality Indicator Measure Development, Implementation, Measurement and Retirement 2011. Agency for Healthcare Research and Quality, Rockville, MD. <http://qualityindicators.ahrq.gov/ Downloads/Resources/Publications/2011/QI\%20Measure\%20 Development\%20Implementation\%20Maintenance\%20 Retirement\%20Full\%205-3-11.pdf> (Accessed September 9, 2013).

30. Odesina V, Bellini S, Delaney C, et al. Evidence-based sickle cell pain management in the emergency department. Adv Emerg Nurs J 2010;18:102-11.

31. Pletcher MJ, Kertesz SG, Kohn MA, Gonzales R. Trends in opioid prescribing by race/ethnicity for patients seeking care in US emergency departments. JAMA 2008;299:70-8.

32. Hawkes C, Kelleher G, Hourihane J. Paediatric analgesia in an emergency department. Ir Med J 2008;101:106-9. 
33. Hwang U, Richardson LD, Sonuyi TO, Morrison RS. The effect of emergency department crowding on the management of pain in older adults with hip fracture. J Am Geriatr Soc 2006;54:270-5.

34. Jackson SE. The efficacy of an educational intervention on documentation of pain management for the elderly patient with a hip fracture in the emergency department. J Emerg Nurs 2010;36:10-5.

35. Terrell KM, Hustey FM, Hwang U, Gerson LW, Wenger NS, Miller DK. Quality indicators for geriatric emergency care. Acad Emerg Med 2009;16:441-9.

36. Ricard-Hibon A, Ducasse JL, Ravaud P, et al. Quality control programme for acute pain management in emergency medicine: A national survey. Eur J Emerg Med 2004;11:198-203.

37. Shah K, Lendrum K. Pain management in an accident and emergency department: How good are we? J Orthopaed Med 2004;26.

38. Vega-Stromberg T, Holmes SB, Gorski LA, Johnson BP. Road to excellence in pain management: Research, outcomes and direction (ROAD). J Nurs Care Qual 2002;17:15-26.

39. Goodacre SW, Roden RK. A protocol to improve analgesia use in the accident and emergency department. J Accid Emerg Med 1996;13:177-9

40. Ritsema TS, Kelen GD, Pronovost PJ, Pham JC. The national trend in quality of emergency department pain management for long bone fractures. Acad Emerg Med 2007;14:163-9.

41. Eder SC, Sloan EP, Todd K. Documentation of ED patient pain by nurses and physicians. Am J Emerg Med 2003;21:253-7.

42. Grant PS. Analgesia delivery in the ED. Am J Emerg Med 2006;24:806-9.

43. Hwang U, Richardson L, Livote E, Harris B, Spencer N, Morrison RS. Emergency department crowding and decreased quality of pain care. Acad Emerg Med 2008;15:1248-55.

44. Chu K, Brown A. Association between access block and time to parenteral opioid analgesia in renal colic: A pilot study. Emerg Med Australas 2009;21:38-42.

45. Forero R, Mohsin M, McCarthy S, et al. Prevalence of morphine use and time to initial analgesia in an Australian emergency department. Emerg Med Australas 2008;20:136-43.

46. Mitchell R, Kelly AM, Kerr D. Does emergency department workload adversely influence timely analgesia? Emerg Med Australas 2009;21:52-8.

47. Tanabe P, Myers R, Zosel A, et al. Emergency department management of acute pain episodes in sickle cell disease. Acad Emerg Med 2007;14:419-25.

48. Pines JM, Shofer FS, Isserman JA, Abbuhl SB, Mills AM. The effect of emergency department crowding on analgesia in patients with back pain in two hospitals. Acad Emerg Med 2010;17:276-83.

49. Guru V, Dubinsky I. The patient vs. caregiver perception of acute pain in the emergency department. J Emerg Med 2000;18:7-12.

50. Kuan SC, Collins NC, Ryan JM, Callanan I. Treating pain in the emergency department. Eur J Emerg Med 2009;17:52-5.

51. Stelfox HT, Bobranska-Artiuch B, Nathens A, Straus SE. Quality indicators for evaluating trauma care: A scoping review. Arch Surg 2010;145:286-95.

52. Alessandrini E, Varadarajan K, Alpern ER, et al. Emergency department quality: An analysis of existing pediatric measures. Acad Emerg Med 2011;18:519-26.

53. Pasman HR, Brandt HE, Deliens L, Francke AL. Quality indicators for palliative care: A systematic review. J Pain Symptom Manage 2009;38:145-56.

54. Pines JM, Hollander JE. Emergency department crowding is associated with poor care for patients with severe pain. Ann Emerg Med 2008;51:1-5.

55. Czarnecki ML, Turner HN, Collins PM, Doellman D, Wrona S, Reynolds J. Procedural pain management: A position statement with clinical practice recommendations. Pain Manag Nurs 2011;12:95-111.
56. Taddio A, Katz J, Ilersich AL, Koren G. Effect of neonatal circumcision on pain response during subsequent routine vaccination. Lancet 1997;349:599-603.

57. Taddio A, Shah V, Gilbert-MacLeod C, Katz J. Conditioning and hyperalgesia in newborns exposed to repeated heel lances. JAMA 2002;288:857-61.

58. Bach S, Noreng MF, Tjellden NU. Phantom limb pain in amputees during the first 12 months following limb amputation, after preoperative lumbar epidural blockade. Pain 1988;33:297-301.

59. Gordon SM, Dionne RA, Brahim J, Jabir F, Dubner R. Blockade of peripheral neuronal barrage reduces postoperative pain. Pain 1997;70:209-15.

60. Stevens BJ, Abbott LK, Yamada J, et al. Epidemiology and management of painful procedures in children in Canadian hospitals. CMAJ 2011;183:E403-10.

61. Puntillo KA, White C, Morris AB, et al. Patients' perceptions and responses to procedural pain: Results from Thunder Project II. Am J Crit Care 2001;10:238-51.

62. Tcherny-Lessenot S, Karwowski-Soulie F, Lamarche-Vadel A Ginsburg C, Brunet F, Vidal-Trecan G. Management and relief of pain in an emergency department from the adult patients' perspective. J Pain Symptom Manage 2003;25:539-46.

63. Chen EH, Shofer FS, Dean AJ, et al. Gender disparity in analgesic treatment of emergency department patients with acute abdominal pain. Acad Emerg Med 2008;15:414-8

64. Heins A, Grammas M, Heins JK, Costello MW, Huang K, Mishra S. Determinants of variation in analgesic and opioid prescribing practice in an emergency department. J Opioid Manag 2006;2:335-40.

65. Platts-Mills TF, Esserman DA, Brown DL, Bortsov AV, Sloane PD, McLean SA. Older US emergency department patients are less likely to receive pain medication than younger patients: Results from a national survey. Ann Emerg Med 2011;60:199-206.

66. Safdar B, Heins A, Homel P, Miner J, Neighbor M, DeSandre P, Todd KH. Impact of physician and patient gender on pain management in the emergency department - a multicenter study. Pain Med 2009;10:364-72.

67. Todd KH, Deaton C, D'Adamo AP, Goe L. Ethnicity and analgesic practice. Ann Emerg Med 2000;35:11-6.

68. Selbst SM, Clark S. Analgesic use in the emergency department. Ann Emerg Med 1990;19:4.

69. Arendts G, Fry M. Factors associated with delay to opiate analgesia in emergency departments. J Pain 2006;7:682-6.

70. Rubin HR, Pronovost P, Diette GB. The advantages and disadvantages of process-based measures of health care quality. Int J Qual Health Care 2001;13:469-74.

71. Clancy CM, Dougherty D, Walker E. The importance of outcomes research in pediatric emergency medicine. Ambul Pediatr 2002;2(4 Suppl):293-300.

72. Downey LV, Zun LS. Pain management in the emergency department and its relationship to patient satisfaction. J Emerg Trauma Shock 2010;3:326-30.

73. Stahmer SA, Shofer FS, Marino A, Shepherd S, Abbuhl S. Do quantitative changes in pain intensity correlate with pain relief and satisfaction? Acad Emerg Med 1998;5:851-7.

74. Kelly AM. Patient satisfaction with pain management does not correlate with initial or discharge VAS pain score, verbal pain rating at discharge, or change in VAS score in the Emergency Department. J Emerg Med 2000;19:113-6.

75. Drendel AL, Brousseau DC, Gorelick MH. Pain assessment for pediatric patients in the emergency department. Pediatrics 2006;117:1511-8.

76. Rupp T, Delaney KA. Inadequate analgesia in emergency medicine. Ann Emerg Med 2004:43:494-503.

77. Green SM. There is oligo-evidence for oligoanalgesia. Ann Emerg Med 2012;60:212-4. 


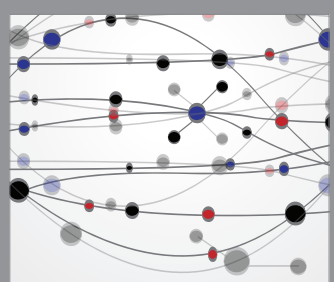

The Scientific World Journal
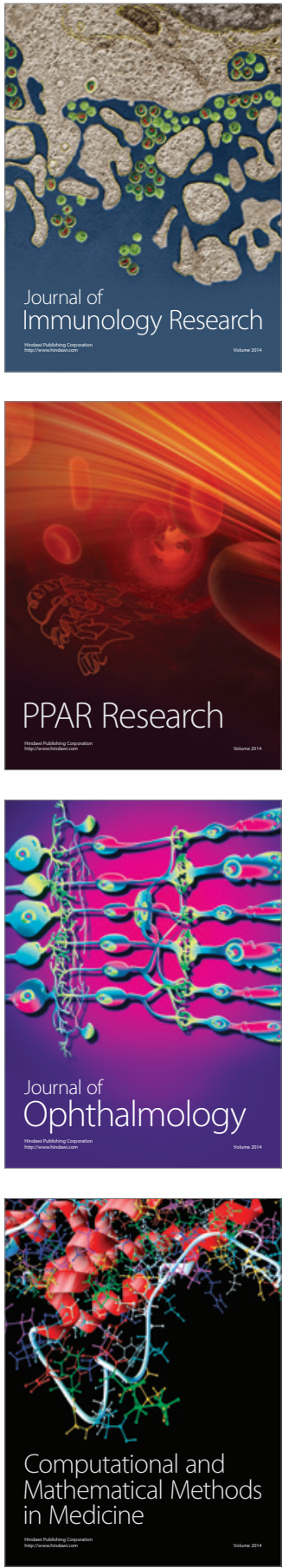

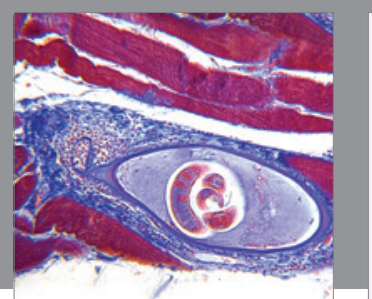

Gastroenterology Research and Practice

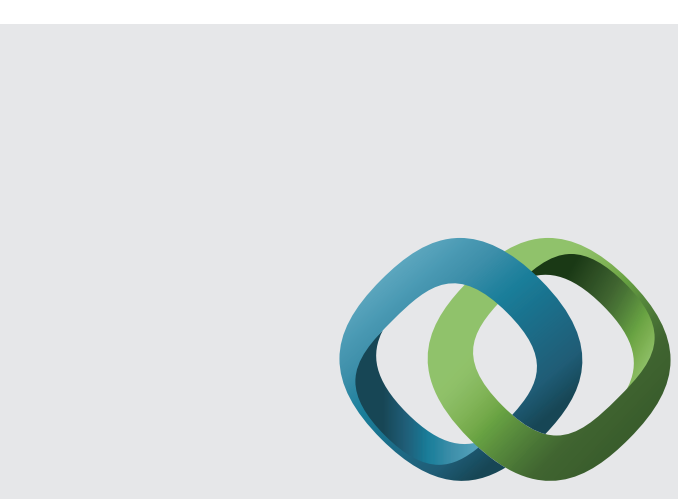

\section{Hindawi}

Submit your manuscripts at

http://www.hindawi.com
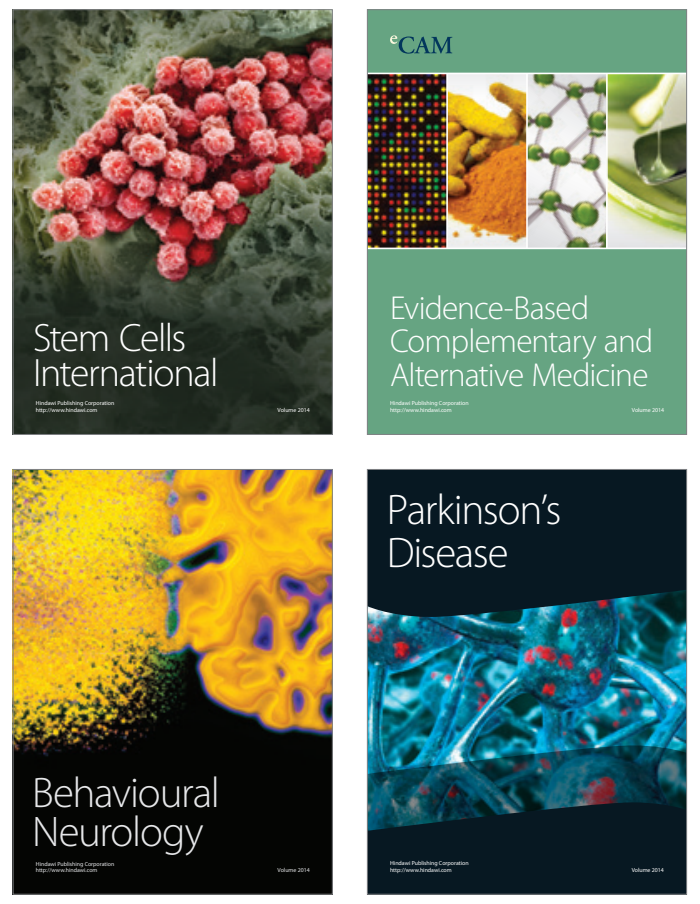
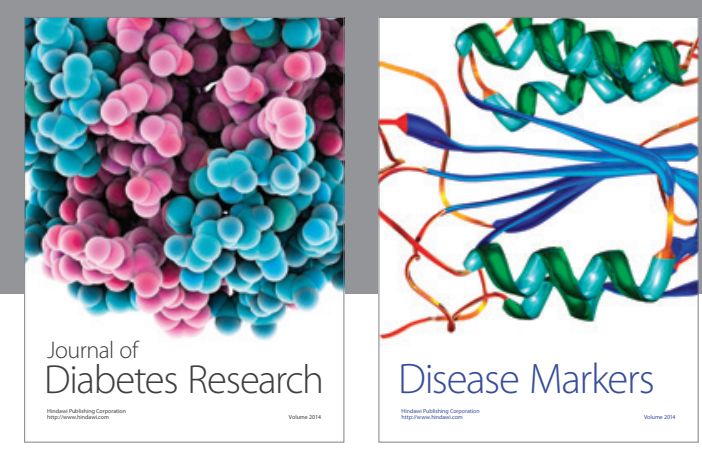

Disease Markers
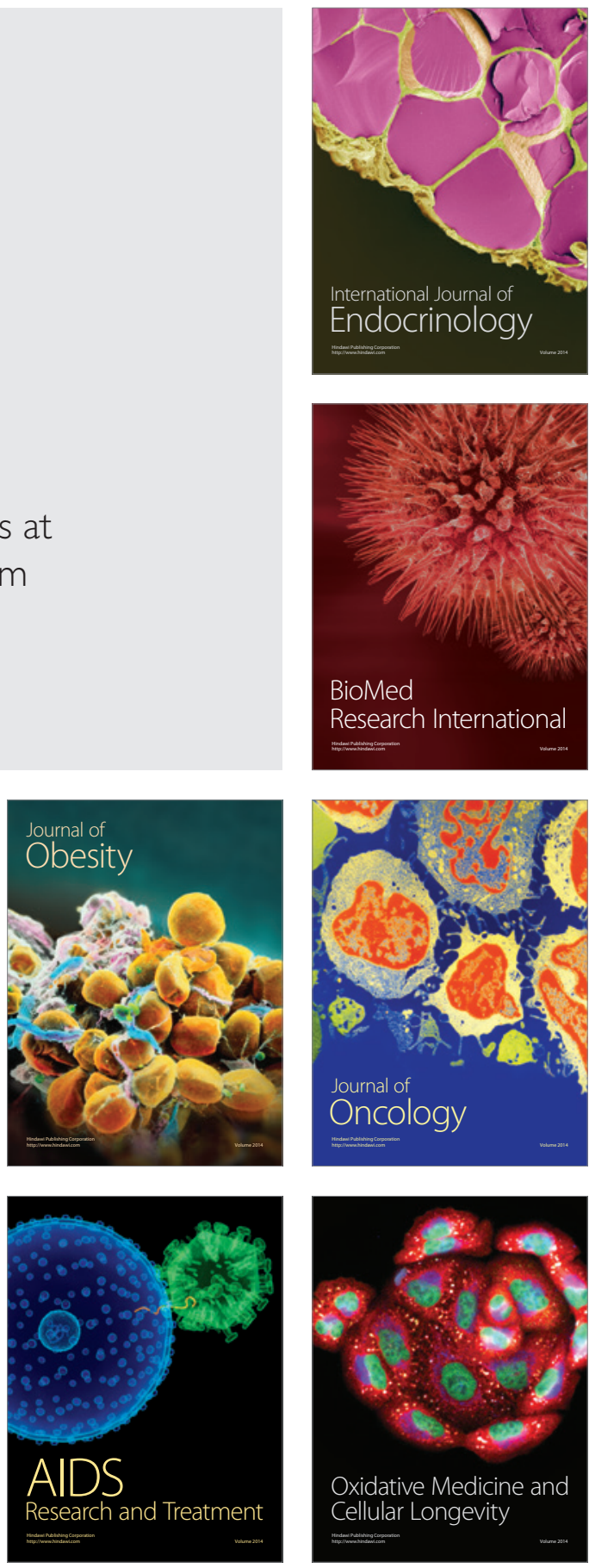